\section{D) Check for updates}

Cite this: Org. Biomol. Chem., 2017, 15,6764

Received 12th June 2017,

Accepted 22nd July 2017

DOI: 10.1039/c7ob01421j

rsc.li/obc

\title{
Amide rotation trajectories probed by symmetry $\dagger$ t
}

\author{
Vladimir Kubyshkin (D) * and Nediljko Budisa (D)*
}

\begin{abstract}
Amide rotation of peptidyl-prolyl fragments is an important factor in backbone structure organization of proteins. Computational studies have indicated that this rotation preferentially proceeds through a defined transition-state structure (syn/exo). Here, we complement the computational findings by determining the amide bond rotation barriers for derivatives of the two symmetric proline analogues, meso and racemic pyrrolidine-2,5-dicarboxylic acids. The rotations around these residues represent syn/exo-syn/exo and anti/endo-syn/exo hybrid transition states for the meso and racemic diastereomer, respectively. The rotation barriers are lower for the former rotation by about $9 \mathrm{~kJ} \mathrm{~mol}^{-1}$ (aqueous medium), suggesting a strong preference for the syn/exo (clockwise) rotation over the anti/endo (anticlockwise) rotation. The results show that both hybrid rotation processes are enthalpically driven but respond differently to solvent polarity changes due to the different transition state dipole-dipole interactions.
\end{abstract}

\section{Introduction}

Proline (1, Fig. 1A) plays an important role in various areas of organic and biological chemistry. These include cellular uptake ${ }^{1}$ metabolism, ${ }^{2}$ translation, ${ }^{3}$ protein folding and engineering, ${ }^{4}$ organocatalysis, ${ }^{5}$ pre-biotic chemistry, ${ }^{6}$ foldamer research, ${ }^{7}$ drug design, ${ }^{8}$ and more. A particularly interesting focus is the tertiary amide bond formed by peptidyl-prolyl fragments in peptide and protein structures. ${ }^{9,10}$ The isomerization of this backbone structure can often become the rate-limiting step in protein folding. ${ }^{11}$ This process is frequently facilitated by peptidyl-prolyl cis-trans isomerases in natural systems $^{12}$ alternatively by substitution of proline with its analogues in laboratory protein expression experiments. ${ }^{13}$ Notably, peptidyl-prolyl isomerization is not necessarily slow compared to other amide bond rotations; rather, it may become rate limiting due to the relative thermodynamic stability of the non-native versus the native state. ${ }^{14}$

The two ground states of the $N$-acyl prolyl amide bond are s-trans and s-cis (Fig. 1B), with s-trans conformation forming preferentially. The preference is about $3: 1$ in Ac-Pro-NHMe, ${ }^{15}$ $4: 1$ in Ac-Pro-OH, ${ }^{16} 5: 1$ in Ac-Pro-OMe, ${ }^{17}$ and $7: 1$ in GlyProGly- $\mathrm{NH}_{2}{ }^{18}$ and AcGlyGlyProGlyGlyNH $\mathrm{H}_{2}$ peptides (water, $298 \mathrm{~K}),{ }^{19}$ which translates to approximately $4-5 \mathrm{~kJ} \mathrm{~mol}^{-1}$ in

Biocatalysis Group, Institute of Chemistry, Technical University of Berlin, Müller-Breslau-Str. 10, Berlin 10623, Germany.E-mail: kubyshkin@win.tu-berlin.de, nediljko.budisa@tu-berlin.de

$\dagger$ The article is dedicated to the memory of Prof. Yuriy Kholin (1962-2017), who nurtured a generation of young talented Ukrainian chemists.

\$Electronic supplementary information (ESI) available: Tables S1-S5, copies of the NMR spectra for compounds. CCDC 1554475 and 1554476. For ESI and crystallographic data in CIF or other electronic format see DOI: 10.1039/c7ob01421j
1

C

unfavored:<smiles>[Y]C[C@H](C)[N+](C)(C)C(=O)O</smiles>

favored:<smiles>[Y]CC(C)(C)[N+](C)([O-])C([Y])=O</smiles>
(dominant)<smiles>O=C([O-])C1CCC[NH2+]1</smiles>

B

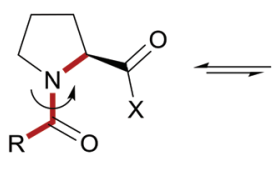

s-trans

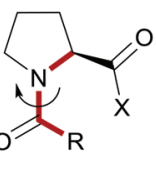

$\mathrm{s}-\mathrm{cis}$

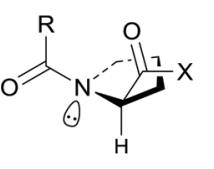

syn/endo

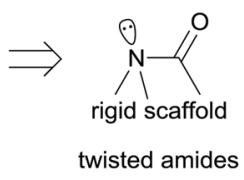

(structural model)

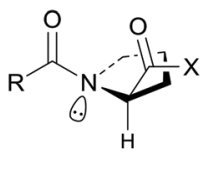

anti/endo
Fig. 1 (A) The structure of proline (1), (B) two $N$-acyl-prolyl ground states, s-trans and s-cis, (C) four possible transition states for the amide rotation, the syn/exo transition state is most favored. The nomenclature is from ref. 21.

energetic preference. At the same time, the amide bond rotation should proceed through one of the four theoretically possible transition states, in which the amide conjugation should be lost (Fig. 1C). Several structures have successfully depicted the non-conjugated state trapped by a rigid molecular scaffold (so-called twisted amides). ${ }^{20}$ However, these elegant structures do not definitively model the amide transition state due to the following reason. Already in the mid-1990s the 
results from a theoretical study showed that the amide rotation preferably proceeds via the syn/exo transition states with the antiparallel orientation of the $\mathrm{N} \rightarrow$ lone pair and carbonyl $\mathrm{C} \rightarrow \mathrm{O}$ dipoles, ${ }^{21}$ whereas in the covalent twisted amides this orientation rather resembles a parallel one. Only very recently metal coordination based twisted amides have been reported, and these demonstrated the antiparallel twist. ${ }^{22}$

Since the seminal theoretical reports, numerous computational studies have demonstrated that the amide rotation around proline has a preference for the syn/exo rotation scenario. $^{23}$ These findings are further supported by recent theoretical $^{24}$ and experimental ${ }^{25}$ studies of the catalytic mechanism of Pin1 peptidyl-prolyl cis-trans isomerase, and experimental demonstration of the self-catalytic mechanism of the amide rotation in nonpolar media. ${ }^{26}$

In the syn/exo transition state, the nitrogen lone pair is oriented on the same side and the carbonyl oxygen rotates into the opposite side with respect to the proline carbonyl group, whereas the upstream alkyl moiety is oriented outward. Curiously, despite the existing consensus among theoretical studies, a proper experimental model that addresses the energetic differences in the relevant rotation modes is lacking. While there is little doubt that the syn/exo transition state is the most relevant, it is not clear whether the anti/endo transition state can contribute to the rotation or whether the properties of the syn/exo conformation can be extrapolated to other transition scenarios. Therefore we designed an experimental model based on derivatives of pyrrolidine-2,5-dicarboxylic acid (Pdc). Pdc has two diastereomeric forms, meso ( $m$ Pdc, with a symmetry plane, $\sigma$ ) and racemic ( $r$ Pdc, with a symmetry axis, $C_{2}$ ). We assumed that the amide ground states are equivalent in the $N$-acyl Pdc derivatives when the acyl-moiety is not chiral. At the same time, we expected the amide rotation to proceed via the syn/exo-syn/exo hybrid state for $m \mathrm{Pdc}$ and the anti/endo-syn/exo hybrid state for $r$ Pdc derivatives (Fig. 2) (using the proline transition state nomenclature, Fig. 1C). We therefore synthesized a series of amides with non-chiral N-terminal acyl
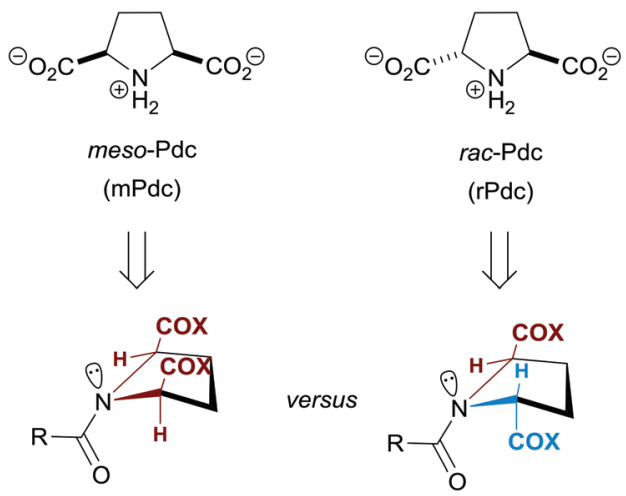

syn/exo - syn/exo

anti/endo - syn/exo

Fig. 2 Design of the study. Two diastereomeric forms of pyrrolidine2,5-dicarboxylic acid yield different rotation modes around the $\mathrm{N}$-acyl derivatives.
mPdc:

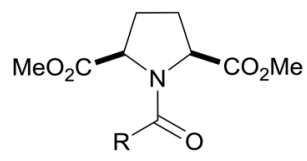

2a $\mathrm{R}=\mathrm{CH}_{3}$

2b R $=\mathrm{C}\left(\mathrm{CH}_{3}\right)_{3}$

2c R $=\mathrm{CH}_{2} \mathrm{NHAC}$

pyrrolidine:

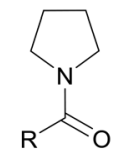

$4 \mathrm{a} \mathrm{R}=\mathrm{CH}_{3}$

4b $\mathrm{R}=\mathrm{C}\left(\mathrm{CH}_{3}\right)_{3}$

$4 \mathrm{c}=\mathrm{CH}_{2} \mathrm{NHAC}$
$\underline{\mathrm{rPdc}}$

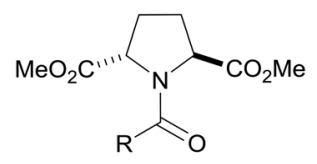

3a $\mathrm{R}=\mathrm{CH}_{3}$

3b $\mathrm{R}=\mathrm{C}\left(\mathrm{CH}_{3}\right)_{3}$

$3 c \mathrm{R}=\mathrm{CH}_{2} \mathrm{NHAC}$

Pro:

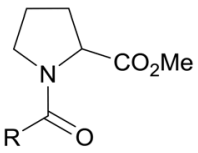

$5 \mathrm{a} \mathrm{R}=\mathrm{CH}_{3}$

5b $\mathrm{R}=\mathrm{C}\left(\mathrm{CH}_{3}\right)_{3}$

5c $\mathrm{R}=\mathrm{CH}_{2} \mathrm{NHAC}$
Fig. 3 Examined compounds.

groups (Fig. 3). Here, we report the experimental amide bond rotation barriers for these two model situations. The results obtained for proline and pyrrolidine derivatives will also be shown for reference but will not be discussed in the context of this paper.

\section{Results and discussion}

\section{The ground state}

We designed our study with the assumption that the amide ground state formed by the Pdc residue will experience similar chemical environments in both diastereomeric situations. The similarity in the through-bond electronic environment of the $\mathrm{N}$-terminal fragment can be assumed from the acidity of the amino acid ammonium salts, which was nearly identical for both Pdc derivatives, as shown in Fig. 4.

Next, the X-ray crystal structures for both $N$-acetyl derivatives 2a and 3a demonstrate fully planar amide bonds (Fig. 5A). ${ }^{27}$ In the $m$ Pdc derivative $2 \mathrm{a}$, the amide conformation breaks the symmetry of the structure and creates two enantiomers, which were present in a ratio of $4: 2$ in the cell unit. In the $r$ Pdc derivative $\mathbf{3 a}$, the amide does not break the existing $C_{2}$ symmetry of the structure, and the cell unit contains a racemate with a $2: 2$ ratio of the $(R, R)$ and $(S, S)$ enantiomers. The envelope conformation of the pyrrolidine ring in proline is usually described in terms of exo-/endo-pucker nomenclature (alternatively called up-/down-) depending on the direction of the $\mathrm{C}^{4}$-atom displacement from the plane of the ring relative to the carboxyl group orientation. Following this nomenclature, the $m$ Pdc derivative 2 a adopts a hybrid of exo- and endopucker, whereas the rPdc derivative 3a is a hybrid of two endopuckers. The crystal structure is consistent with the solution ${ }^{1} \mathrm{H}$ NMR spectra, in which the two $\mathrm{CH}\left(\mathrm{CO}_{2} \mathrm{Me}\right)$ resonances 


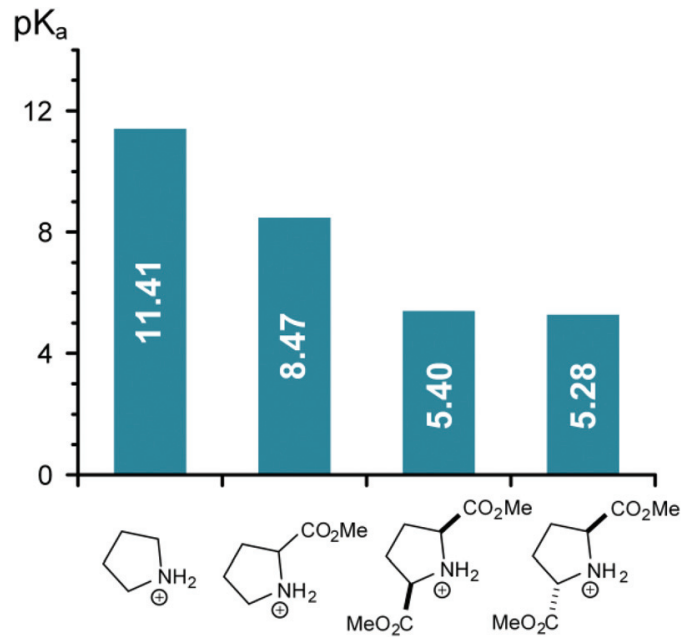

Fig. 4 The $\mathrm{p} K_{\mathrm{a}}$ of the ammonium group in the pyrrolidine-2,5-dicarboxylic acid derivatives. The data on pyrrolidine and proline methyl esters are included for comparison. Standard error: \pm 0.10 .

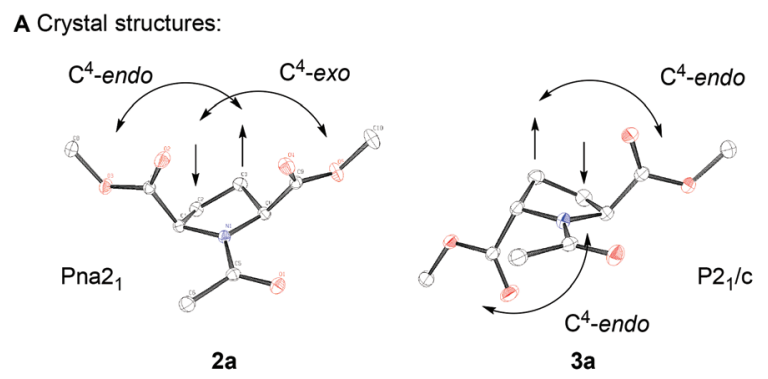

B ${ }^{1} \mathrm{H}$ NMR multiplicities of the $\mathrm{CH}$-fragments (in $\mathrm{D}_{2} \mathrm{O}$ ):
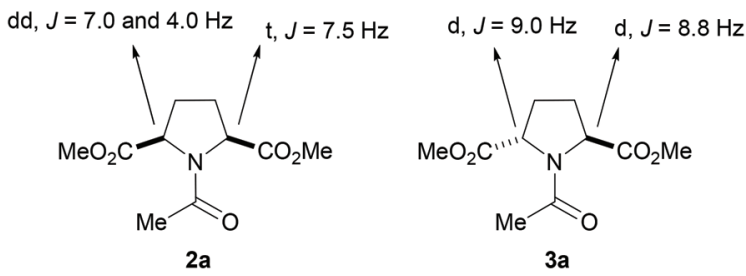

Fig. 5 The X-ray crystal structures (A) and solution ${ }^{1} \mathrm{H}$ NMR (in $\mathrm{D}_{2} \mathrm{O}$ ) data (B) for the $\mathrm{N}$-acetyl compounds $2 \mathrm{a}$ and $3 \mathrm{a}$. The ellipsoids represent $30 \%$ probability displacement, carbon - black, oxygen - red, and nitrogen - blue.

appear as a triplet and doublet of doublets in $2 \mathbf{a}$ and as two doublets in 3a (Fig. 5B). ${ }^{28}$ Importantly, these NMR spectral signatures persisted in all examined Pdc derivatives and in all employed NMR solvents (see 'Polar effects').

Based on this spatial organization argument we expect the steric requirements to be identical around the methyl group of the acetyl moiety, whereas the environment of the carbonyl group is different. These differences are very well described in the proline literature in terms of the pre-organization of the $\mathrm{n} \rightarrow \pi^{*}$ interaction between the carbonyl groups. ${ }^{29}$ As a result, some additional stability of about $1-3 \mathrm{~kJ} \mathrm{~mol}^{-1}$ can be expected for the $m \mathrm{Pdc}$ derivatives relative to the $r \mathrm{Pdc}$-derived compounds irrespective from the polarity of the medium. ${ }^{17}$

Another aspect is the $\psi$-torsion due to the rotation of the carboxyl-group. For the proline derivative this rotation yields two states $\psi_{1} \sim 170^{\circ}$ and $\psi_{2} \sim-20^{\circ}$ with different polarities. In 5a the first state is preferred by about $1.3-2.5 \mathrm{~kJ} \mathrm{~mol}^{-1} \cdot{ }^{30} \mathrm{We}$ modelled the carboxyl-group rotation in $\mathbf{2 a - 3 a}$, and found that this preference remains nearly identical for the $r$ Pdc derivative 3a $\left(\Delta \Delta G_{\psi_{1} / \psi_{2}} \sim 1.6-2.7 \mathrm{~kJ} \mathrm{~mol}^{-1}\right)$, whereas in 2a the two carboxymethyl groups are more proximal, and the rotation state difference becomes more prominent $\left(\Delta \Delta G_{\psi_{1} / \psi_{2}} \sim 3.7-4.7 \mathrm{~kJ} \mathrm{~mol}^{-1}\right)$. This, however, produces only a little energy difference between the two ground states, and the resulting polarity differences are expected to become influential only in nonpolar media. ${ }^{30}$

Hereafter, we will not correct for these energies and will consider both ground states equivalent for simplicity of presentation.

\section{Energetic terms of the amide rotation}

We then analyzed the amide rotation barriers in the $\mathrm{N}$-acetyl derivatives $\mathbf{2 a}, \mathbf{3 a}$ and $\mathbf{4 a}$ in aqueous medium by ${ }^{1} \mathrm{H}$ EXSY NMR. The results are shown in Fig. 6, where the activation energy values $E^{\neq}$are presented as a function of temperature (also see Table S1 ). As expected, the rotation barrier for the $m$ Pdc derivative 2a was remarkably lower compared to the $r$ Pdc derivative $3 a$ (by $9.3-9.5 \mathrm{~kJ} \mathrm{~mol}^{-1}$; equivalent to a factor of $43-46$ at $298 \mathrm{~K})$.

For all three examined structures, the amide rotation is an enthalpically defined process with a small negative slope, $-T \Delta S^{\neq}\left(\Delta S^{\neq}>0\right)$. The smallest entropic contribution was found for pyrrolidine derivative $4 \mathbf{a}\left(\Delta S^{\neq}=+3.2 \pm 1.8 \mathrm{~J} \mathrm{~mol}^{-1} \mathrm{~K}^{-1}\right)$, whereas for the $m$ Pdc derivative $2 \mathrm{a}$, this value was somehow larger $\left(\Delta S^{\neq}=+11.9 \pm 0.9 \mathrm{~J} \mathrm{~mol}^{-1} \mathrm{~K}^{-1}\right)$. We were not able to determine the entropic value for the $r$ Pdc derivative 3a with the same level of accuracy $\left(\Delta S^{\neq}=+7.6 \pm 9.0 \mathrm{~J} \mathrm{~mol}^{-1} \mathrm{~K}^{-1}\right)$ due to the high relative experimental error for the very slow rates under the lower temperature conditions. Nonetheless, this lack of accuracy does not affect the overall conclusion, as the same tendencies were found for the $N$-acetylglycyl derivatives

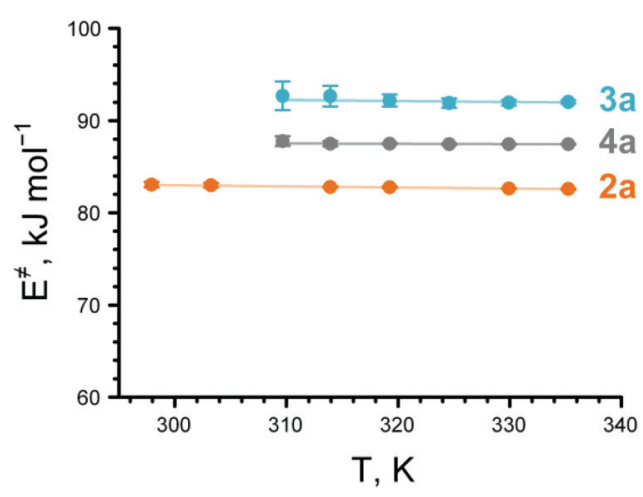

Fig. 6 Amide rotation barriers for the $N$-acetyl derivatives $2 a$, 3a and $4 a$ as a function of temperature, measured by ${ }^{1} \mathrm{H}$ EXSY NMR in deuterium oxide. For details, see Tables S1 and S3. 
2c-4c. In the latter case, the activation enthalpy was reduced by $5-7 \mathrm{~kJ} \mathrm{~mol}^{-1}$ and the entropy was reduced by 6-9 $\mathrm{J} \mathrm{mol}^{-1}$ $\mathrm{K}^{-1}$ relative to the $N$-acetyl derivatives (see Tables S2 and S3 $\$$ ).

A small positive activation entropy is also known for the amide rotation in the proline derivative $\mathbf{5 a}$, where $\Delta S^{\neq}$has been reported to be +9.0 for cis $\rightarrow$ trans and $+12.8 \mathrm{~J} \mathrm{~mol}^{-1} \mathrm{~K}^{-1}$ for trans $\rightarrow$ cis rotations, respectively. ${ }^{31,32}$ The positive entropy of the amide rotation process may originate from the higher molecular rigidity of the ground state (featured by the $\mathrm{n} \rightarrow \pi^{*}$ interactions, for instance), ${ }^{17,29}$ as well as the stronger polar interactions of the ground state with water (organization of the solvent). For example, negative activation entropy for the amide rotation in Ac-AA-OMe has been reported for some proline analogues with additional polar groups, ${ }^{33}$ nonetheless, for some other polar proline analogues this value was also positive. $^{34}$

\section{Steric bulk of the $N$-acyl substituent}

We then measured the amide rotation barriers for the full set of the prepared compounds in deuterium oxide medium (Fig. 7 and Table S4 $\ddagger$ ). The $N$-acetyl (2a-5a) and $N$-pivaloyl derivatives $(\mathbf{2} \mathbf{b}-\mathbf{5} \mathbf{b})$ feature the same high symmetry of the acyl moieties, while the steric bulk of the alkyl groups is significantly different. Due to the much higher steric size, the ground state is largely destabilized in the $N$-pivaloyl derivatives, and the overall difference from the $N$-acetyl compounds is about $15-21 \mathrm{~kJ} \mathrm{~mol}^{-1}$ (equivalent to a factor of 500-5000 at $298 \mathrm{~K})$. At the same time, the bulky pivaloyl group excludes the possibility of the anti/exo or syn/endo transition state situations (proline nomenclature, see Fig. 1C), in which the tert-butyl group should move under the pyrrolidine ring. According to our semi-empirical modelling, these will be disfavored by about $11-12 \mathrm{~kJ} \mathrm{~mol}^{-1}$ in both $N$-pivaloyl derivatives $\mathbf{2 b}-\mathbf{3} \mathbf{b}$, whereas in the $N$-acetyl compounds $\mathbf{2 a}-\mathbf{3 a}$ the disfavor is only by about $4-5 \mathrm{~kJ} \mathrm{~mol}^{-1}$. Finally, the $N$-acetylglycyl derivatives 2c-5c represent a symmetric $N$-peptidyl-substitution, and the rotation barriers here were reduced by about $3 \mathrm{~kJ} \mathrm{~mol}^{-1}$ (a factor of 3-4 at $298 \mathrm{~K}$ ) compared to $\mathrm{N}$-acetyl compounds 2a-5a. Notably, the amide rotation barriers found for the C-terminal methyl ester derivative of proline $5 \mathbf{c}$ are identical to the barriers found for the C-terminal peptidyl derivative AcGlyGlyProGlyGlyNH ${ }_{2},{ }^{19}$ and from this we may conclude that the C-terminal ester adequately models the amide rotation in the polar medium such as water.

Importantly, for all three types of tested compounds, the rotation barrier difference between the Pdc derivatives was about 8-10 kJ mol${ }^{-1}$ (a factor of $25-55$ at $298 \mathrm{~K}$ ), with the barriers always lower for the $m$ Pdc derivative. This result confirms that the rotation barrier difference in this case originates from the transition state structures. It also highlights the fact that in both the syn/exo and anti/endo transition states shown in Fig. 1C, the alkyl group of the acetyl moiety moves outwards and cannot sterically interfere with the substituents in the pyrrolidine ring (see also Fig. 2). On the other hand, the carbonyl group of the amide fragment moves towards the pyrrolidine ring and may sterically interfere with a carboxymethyl group in $r$ Pdc derivatives and create polar interactions with the carboxymethyl groups in both $r$ Pdc and $m$ Pdc derivatives.

\section{Polar effects}

The polar interactions between the amide and carboxymethyl groups were then studied by comparison of the rotation barriers of the $N$-acetyl compounds (2a, $3 \mathbf{a}$ and $\mathbf{4 a}$ ) in a set of nine NMR solvents (see Table S5 $\$$ ). It is well known that the conjugation in the amide ground state is highly dependent on the solvent polarity; ${ }^{9,35}$ mechanistically, this is illustrated by the change in the amide resonance contributions $[\mathrm{O}=\mathrm{C}-\mathrm{N} \leftrightarrow$ $\left.{ }^{-} \mathrm{O}-\mathrm{C}=\mathrm{N}^{+}\right]$. The Reichardt-Dimroth parameter $\left(E_{\mathrm{T}}\right)$ is a solvatochromic value that quantifies the ability of a solvent to separate intramolecular charges. Therefore, plotting rotation barriers in the $E^{\neq}-E_{\mathrm{T}}$ coordinates produces positive slopes due to the differences in the ground state stabilities. ${ }^{16}$

While the experimental slopes (Fig. 8) for the $r$ Pdc and pyrrolidine derivatives (3a and $\mathbf{4 a}$ ) were nearly identical $(0.076 \pm$ 0.006 and $0.075 \pm 0.010$, respectively), the slope for the $m \mathrm{Pdc}$ derivative $(2 a)$ was notably larger $(0.088 \pm 0.008)$. This result illustrates differences in the polar effects of the transition states. We performed semi-empirical modelling of the amide rotation, and found that the overall molecular dipole follows the orientation of the amide carbonyl group $\mathrm{C}=\mathrm{O}$ in the pyrro-
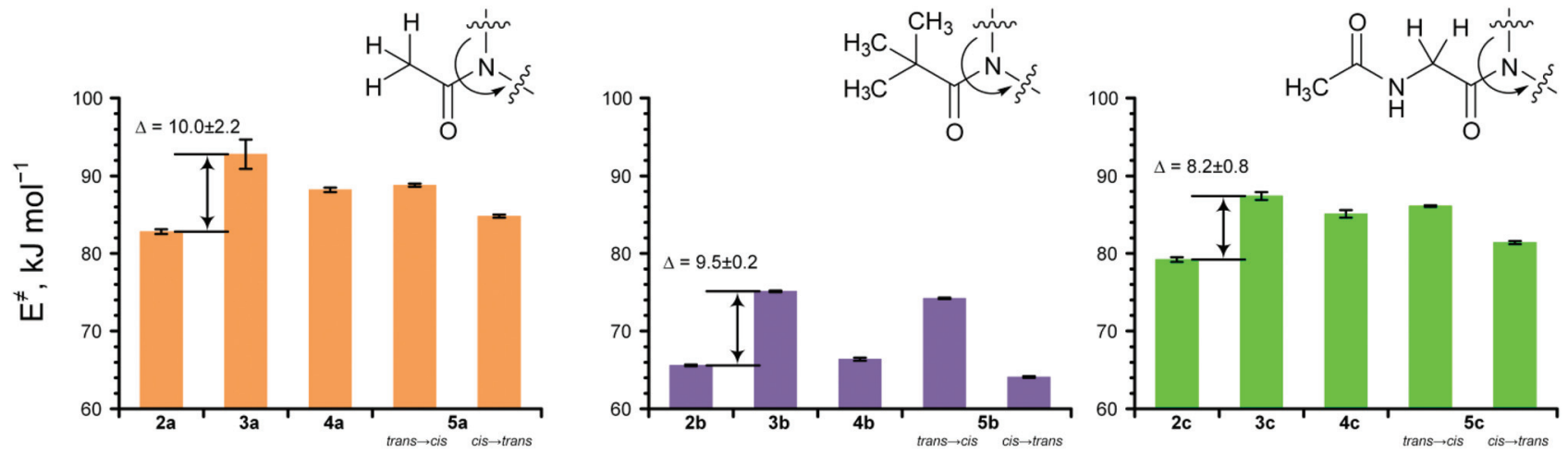

Fig. 7 Amide rotation barriers of $\mathrm{N}$-acyl derivatives. The values were determined in deuterium oxide solution (for AcGly-derivatives, buffered at $\mathrm{pH}$ 7 with potassium phosphate buffer) at 298 or $310 \mathrm{~K}$. See ESI Table S4\$ for details. 


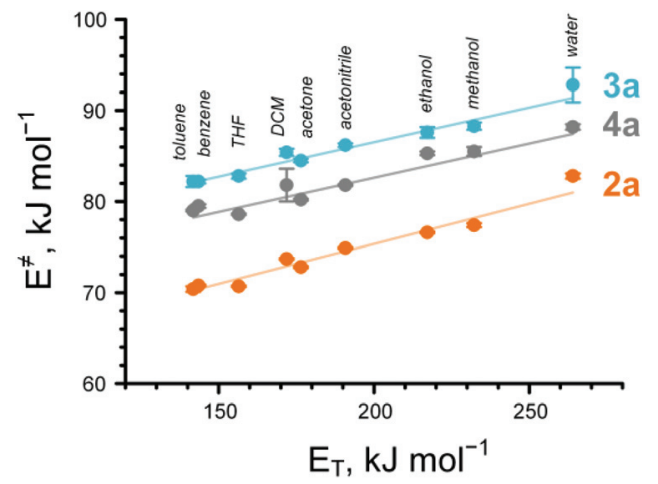

Fig. 8 Amide rotation barriers for the $N$-acetyl derivatives $2 a$, 3a and $4 a$ measured in different solvents by ${ }^{1} \mathrm{H}$ EXSY NMR (at 298 or $310 \mathrm{~K}$ ). For details see ESI Table S4.\$

lidine derivative $\mathbf{4 a}$, and in the $r \mathrm{Pdc}$ derivative $\mathbf{3 a}$. In the latter compound the dipolar contribution of both carboxymethylmoieties is mutually compensated for by the $C_{2}$-symmetry of the residue (Fig. 9). As a result, the overall molecular dipole is defined by the orientation of the amide carbonyl group, and effectively, both $3 \mathbf{a}$ and $4 \mathbf{a}$ yield the same slope in the $E^{\neq}-E_{\mathrm{T}}$ coordinates.

The orientation of the molecular dipole in $2 \mathbf{a}$ is more complex. The configuration of the two carboxymethyl substituents renders the compound more polar than 3a. For example, the $R_{\mathrm{f}}$ of $m$ Pdc derivatives are consistently lower compared with the equivalent $r$ Pdc derivatives (see the Experimental section). Higher polarity of the meso-diastereomer is also inferred from the octan-1-ol/water partitioning values as shown in Fig. 9. The amide rotation via the putative syn/exo-

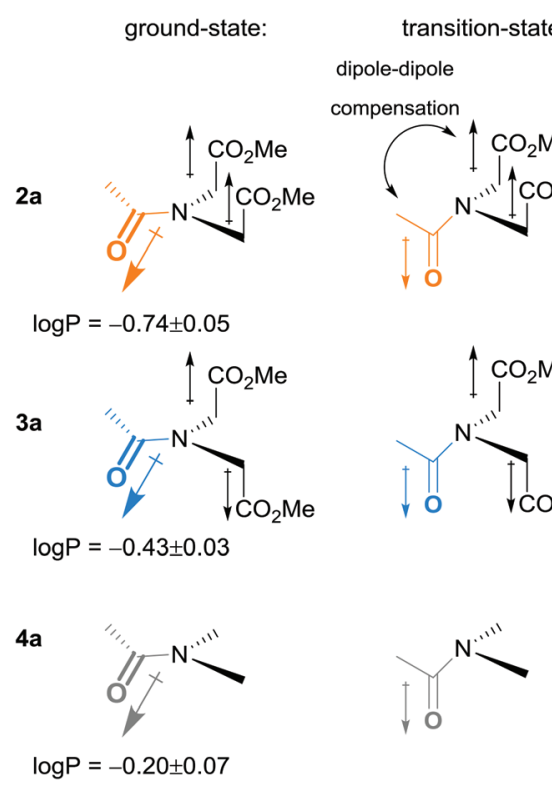

Fig. 9 Schematic representation of the dipolar effects during the amide rotation in $\mathrm{N}$-acetylated compounds. $\log P$ values represent partitioning of the compounds between octan-1-ol and water at $298 \mathrm{~K}$. syn/exo hybrid transition state partially compensates for the intramolecular dipole-dipole interaction in the transition state, causing the transition state to be relatively favored in the nonpolar solvents. As a result, the slope in the $E^{f}-E_{\mathrm{T}}$ coordinates increases for 2a. Similar dipolar compensation can be expected for the amide rotation via the syn/exo transition state in peptidyl-prolyl fragments, and this effect might be enhanced due to a higher polarity of the amide fragment versus the esters reported here. As a result, the syn/exo transition state dominance should increase in less polar environments.

\section{Conclusions}

In summary, we described the amide rotation properties in $N$-acyl pyrrolidine-2,5-dicarboxylic acid derivatives, capped at the C-terminal sides as methyl esters. The meso diastereomer of this compound exhibited an amide rotation barrier of approximately $9 \mathrm{~kJ} \mathrm{~mol}^{-1}$ lower than that of the racemic diastereomer. This outcome was reproducible in three $N$-acyl derivatives with different degrees of steric bulk of the acyl-moieties to represent varying ground state energies.

This model system allowed us to demonstrate experimental features of the amide rotation relevant for peptidyl-prolyl groups: (1) the transitions are enthalpically driven and (2) differ in dipole-dipole compensation levels in the transition states and (3) the syn/exo transition scheme prevails in general over the anti/endo. These conclusions are consistent with the results of computational studies, which suggested the dominance of the syn/exo over the anti/endo transition state. At the same time, the other theoretically possible transition states, anti/exo and especially syn/endo, are expected to be disfavoured in peptide structures, as these would require the movement of a bulky upstream peptidyl-fragment under the pyrrolidine ring of proline.

\section{Experimental section}

\section{Synthesis}

$N$-Benzyl derivatives of Pdc were prepared starting from adipic acid as a mixture of two diastereomers. ${ }^{36}$ The resulting Bn(MeO)Pdc-OMe compounds were separated on a silica gel column using hexane-ethyl acetate $(4: 1)$ as an eluent $\left(R_{\mathrm{f}}=\right.$ 0.48 for $r \mathrm{Pdc}$ and 0.27 for $m \mathrm{Pdc}$ derivatives). The ${ }^{1} \mathrm{H}$ NMR spectra exhibit a characteristic $\mathrm{AB}$ system for the diastereotopic benzyl $\mathrm{CH}_{2}$ group in the $r \mathrm{Pdc}$ derivative, whereas this signal is a singlet in the $m$ Pdc derivative, where the $\mathrm{CH}_{2}$ moiety is not diastereotopic. ${ }^{1} \mathrm{H}$ NMR $\left(500 \mathrm{MHz}, \mathrm{CDCl}_{3}\right), \delta$ : Bn-(MeO)mPdcOMe, 7.44-7.32 (m, 5H), 4.05 (s, 2H), 3.68 (s, 6H), 3.59 (br, 2H), 2.18 (m, 4H); Bn-(MeO)rPdc-OMe, 7.44-7.32 (m, 5H), 4.11 (d, $J=13 \mathrm{~Hz}, 1 \mathrm{H}), 3.92(\mathrm{br} \mathrm{d}, J=7 \mathrm{~Hz}, 2 \mathrm{H}), 3.91(\mathrm{~d}, J=13 \mathrm{~Hz}$, $1 \mathrm{H}), 3.75(\mathrm{~s}, 6 \mathrm{H}), 2.42(\mathrm{~m}, 2 \mathrm{H}), 2.04(\mathrm{~m}, 2 \mathrm{H})$. The removal of the $N$-benzyl group was performed by stirring the substance with palladium on charcoal $(10 \%)$ in methanol acidified with 
an equivalent amount of hydrochloric acid, under hydrogen pressure $(40 \mathrm{~atm})$, at $35{ }^{\circ} \mathrm{C}$. The reaction was monitored by NMR. After the reaction was complete, the mixture was filtered, the solvent was removed under reduced pressure, and the residue was dissolved in water, filtered with activated charcoal and freeze-dried. The amino acid hydrochlorides were obtained as pinkish powders. ${ }^{1} \mathrm{H}$ NMR $(700 \mathrm{MHz}$, $\left.\mathrm{CD}_{3} \mathrm{OD}\right), \delta$ : HCl.H-(MeO)mPdc-OMe, $4.33(\mathrm{t}, J=6 \mathrm{~Hz}, 2 \mathrm{H})$, $3.85(\mathrm{~s}, 6 \mathrm{H}), 2.40(\mathrm{~m}, 2 \mathrm{H}), 2.15(\mathrm{~m}, 2 \mathrm{H}) ; \mathrm{HCl} \cdot \mathrm{H}-(\mathrm{MeO})$ rPdc-OMe, $4.22(\mathrm{t}, J=6 \mathrm{~Hz}, 2 \mathrm{H}), 3.80(\mathrm{~s}, 6 \mathrm{H}), 2.32(\mathrm{~m}, 2 \mathrm{H})$, $2.06(\mathrm{~m}, 2 \mathrm{H})$.

$\mathrm{N}$-Acetyl compounds. $\mathrm{N}$-Acetyl compounds were prepared as follows. A salt $\mathrm{HCl} \cdot \mathrm{H}-(\mathrm{MeO}) \mathrm{Pdc}-\mathrm{OMe}(\mathrm{Pdc}=m \mathrm{Pdc}$ or $r \mathrm{Pdc}$, $101 \mathrm{mg}, 0.45 \mathrm{mmol})$ was stirred with acetic anhydride $(0.4 \mathrm{ml}$, $4.2 \mathrm{mmol}, 9$ equiv.), triethylamine ( $0.2 \mathrm{ml}, 1.4 \mathrm{mmol}, 3$ equiv.) and dimethylaminopyridine ( $5 \mathrm{mg}, 0.04 \mathrm{mmol}, 9 \mathrm{~mol} \%$ ) in a dichloromethane-tetrahydrofuran mixture $(1.5 \mathrm{ml}, 2: 1)$ for 48 hours at room temperature. The solvent was gently removed under nitrogen gas flow, and the residue was dissolved in water $(0.7 \mathrm{ml})$ and freeze-dried. The crude material was purified on a short silica gel column (about $10 \mathrm{~g}$ ) using an ethyl acetate-methanol mixture $(19: 1)$ as an eluent $\left(R_{\mathrm{f}}=0.49\right.$ for $2 \mathrm{a}$ and 0.63 for $3 \mathbf{a})$.

Dimethyl(r,s)-1-acetylpyrrolidine-2,5-dicarboxylate

(2a).

Yellowish solid, yield $84 \mathrm{mg}$ (0.37 mmol, 81\%). ${ }^{1} \mathrm{H}$ NMR (700 MHz, D $\mathrm{D}_{2} \mathrm{O}$ ), $\delta: 4.74(\mathrm{dd}, J=7.0,4.0 \mathrm{~Hz}, 1 \mathrm{H}), 4.44(\mathrm{t}, J=7.5$ $\mathrm{Hz}, 1 \mathrm{H}), 3.75(\mathrm{~s}, 3 \mathrm{H}), 3.69(\mathrm{~s}, 3 \mathrm{H}), 2.33-2.26(\mathrm{~m}, 3 \mathrm{H}), 2.03(\mathrm{~s}$, $3 \mathrm{H}), 1.92(\mathrm{~m}, 1 \mathrm{H}) .{ }^{13} \mathrm{C}\left\{{ }^{1} \mathrm{H}\right\}$ NMR (176 MHz, $\left.\mathrm{D}_{2} \mathrm{O}\right), \delta$ (all singlets): $173.9(\mathrm{C}=\mathrm{O}), 173.8(\mathrm{C}=\mathrm{O}), 173.3(\mathrm{C}=\mathrm{O}), 61.2(\mathrm{CH}), 60.1$ $(\mathrm{CH}), 53.1\left(\mathrm{CH}_{3} \mathrm{O}\right), 52.8\left(\mathrm{CH}_{3} \mathrm{O}\right), 29.4\left(\mathrm{CH}_{2}\right), 27.7\left(\mathrm{CH}_{2}\right), 21.2$ $\left(\mathrm{CH}_{3}\right)$. HMRS (ESI-orbitrap): calcd for $[\mathrm{M}+\mathrm{H}]^{+} \mathrm{C}_{10} \mathrm{H}_{16} \mathrm{NO}_{5}$ 230.1023 Da, found 230.1028 Th. M.p. $60-65{ }^{\circ} \mathrm{C}$.

Dimethyl(r,r)-1-acetylpyrrolidine-2,5-dicarboxylate (3a). White solid, yield $85 \mathrm{mg}(0.37 \mathrm{mmol}, 82 \%) .{ }^{1} \mathrm{H}$ NMR (700 MHz, $\left.\mathrm{D}_{2} \mathrm{O}\right)$, $\delta: 4.82(\mathrm{~d}, J=9.0 \mathrm{~Hz}, 1 \mathrm{H}), 4.54(\mathrm{t}, J=8.8 \mathrm{~Hz}, 1 \mathrm{H}), 3.75(\mathrm{~s}, 3 \mathrm{H})$, $3.69(\mathrm{~s}, 3 \mathrm{H}), 2.36(\mathrm{~m}, 1 \mathrm{H}), 2.22(\mathrm{~m}, 2 \mathrm{H}), 2.05(\mathrm{~m}, 1 \mathrm{H}), 2.00(\mathrm{~s}$, 3H). ${ }^{13} \mathrm{C}\left\{{ }^{1} \mathrm{H}\right\}$ NMR (176 MHz, $\left.\mathrm{D}_{2} \mathrm{O}\right), \delta$ (all singlets): 174.2 $(\mathrm{C}=\mathrm{O}), 174.0(\mathrm{C}=\mathrm{O}), 173.7(\mathrm{C}=\mathrm{O}), 61.1(\mathrm{CH}), 59.5(\mathrm{CH}), 53.4$ $\left(\mathrm{CH}_{3} \mathrm{O}\right), 53.0\left(\mathrm{CH}_{3} \mathrm{O}\right), 29.2\left(\mathrm{CH}_{2}\right), 27.0\left(\mathrm{CH}_{2}\right), 21.1\left(\mathrm{CH}_{3}\right)$. HMRS (ESI-orbitrap): calcd for $[\mathrm{M}+\mathrm{H}]^{+} \mathrm{C}_{10} \mathrm{H}_{16} \mathrm{NO}_{5} 230.1023 \mathrm{Da}$, found 230.1030 Th. M.p. $95-100{ }^{\circ} \mathrm{C}$.

The proline derivative Ac-Pro-OMe (5a) was prepared by mixing commercial racemic $\mathrm{HCl}$-Pro-OMe with an equivalent amount of acetic anhydride in dichloromethane solution. The solvent was removed under reduced pressure, and the crude material was purified using a hexane-ethyl acetate gradient elution (from $1: 1$ to $0: 1$ ). The substance was obtained as clear oil, which crystallized upon long time storage at $4{ }^{\circ} \mathrm{C}$. White solid, m.p. $35-40{ }^{\circ} \mathrm{C} .{ }^{1} \mathrm{H}$ NMR $\left(700 \mathrm{MHz}, \mathrm{D}_{2} \mathrm{O}\right.$ ), $\delta$ (two rotamers, $K_{\text {trans/cis }} 4.95 \pm 0.05$ at $298 \mathrm{~K}$ ): 4.62 (s-cis, dd, $J=8.8$, $2.6 \mathrm{~Hz}$ ) and 4.36 (s-trans, dd, $J=8.8,4.6 \mathrm{~Hz}, 1 \mathrm{H}, \alpha-\mathrm{CH}), 3.72(\mathrm{~s}-$ cis, s) and 3.67 (s, s-trans, $3 \mathrm{H}, \mathrm{CH}_{3} \mathrm{O}$ ), 3.59 and 3.55 (s-trans, two $\mathrm{m}$ ) and 3.46 and 3.39 (s-cis, two $\mathrm{m}, 2 \mathrm{H}, \delta-\mathrm{CH}_{2}$ ), 2.28 and 2.15 (s-cis, two $\mathrm{m}$ ) and 2.23 and 1.94 (s-trans, two $\mathrm{m}, 2 \mathrm{H}$, $\beta-\mathrm{CH}_{2}$ ), 2.05 (s-trans, s) and 1.93 (s-cis, s, 3H, $\mathrm{CH}_{3} \mathrm{C}=\mathrm{O}$ ), 1.95 (s-trans, $\mathrm{m}$ ) and 1.90 and 1.80 (s-cis, two $\mathrm{m}, 2 \mathrm{H}, \gamma-\mathrm{CH}_{2}$ ).
$\mathrm{N}$-Acetyl pyrrolidine $\mathbf{4 a}$ was prepared as follows. Pyrrolidine $(0.25 \mathrm{ml}, 3 \mathrm{mmol})$ was mixed with acetic anhydride $(0.29 \mathrm{ml}$, $3 \mathrm{mmol}, 1$ equiv.) in dichloromethane $(5 \mathrm{ml}$ ) (CAUTION: vigorous reaction!). The mixture was stirred at room temperature for $30 \mathrm{~min}$. Sodium carbonate $(0.3 \mathrm{~g})$ was added, and this mixture was shaken for about 15 hours at room temperature. The mixture was filtered, and the solvent was removed under reduced pressure to give $\mathbf{4 a}$ as a clear liquid. Yield $0.26 \mathrm{~g}$ (2.3 mmol, 75\%). ${ }^{1} \mathrm{H}$ NMR (500 MHz, $\mathrm{D}_{2} \mathrm{O}$ ), $\delta: 3.41$ (t, $J=7.0$ $\mathrm{Hz}, 2 \mathrm{H}), 3.28$ (t, $J=7.0 \mathrm{~Hz}, 2 \mathrm{H}), 1.97(\mathrm{~s}, 3 \mathrm{H}), 1.86(\mathrm{~m}, 2 \mathrm{H}), 1.79$ $(\mathrm{m}, 2 \mathrm{H})$.

$\mathrm{N}$-Pivaloyl compounds. $\mathrm{N}$-Pivaloyl compounds were prepared according to the procedure for the synthesis of $\mathbf{5 b} .{ }^{37} \mathrm{~A}$ salt $\mathrm{HCl} \cdot \mathrm{H}-(\mathrm{MeO}) \mathrm{Pdc}-\mathrm{OMe}(\mathrm{Pdc}=m \mathrm{Pdc}$ or $r \mathrm{Pdc}, 101 \mathrm{mg}$, $0.45 \mathrm{mmol})$ was mixed with pivaloyl chloride $(70 \mu \mathrm{l}$, $0.57 \mathrm{mmol}, 1.3$ equiv.) in dichloromethane $(1.5 \mathrm{ml})$, followed by the addition of triethylamine ( $150 \mu \mathrm{l}, 1.08 \mathrm{mmol}, 2.4$ equiv.) and dimethylaminopyridine ( $5 \mathrm{mg}, 0.04 \mathrm{mmol}, 9 \mathrm{~mol} \%$ ). The mixture was stirred at room temperature for 4 hours. Then, it was washed with water $(1 \times 0.3 \mathrm{ml}), 1 \mathrm{M}$ aqueous hydrochloric acid $(1 \times 0.3 \mathrm{ml})$ and $1 \mathrm{M}$ sodium hydrogencarbonate solution $(1 \times 0.3 \mathrm{ml})$, and subsequently dried over sodium sulphate, filtered and evaporated. The crude material was purified on a silica gel column (about $5 \mathrm{~g}$ ), using a hexane-ethyl acetate mixture $(1: 1)$ as an eluent $\left(R_{\mathrm{f}}=0.41\right.$ for $2 \mathbf{b}$ and 0.51 for $\left.3 \mathbf{b}\right)$.

Dimethyl(r,s)-1-pivaloylpyrrolidine-2,5-dicarboxylate

(2b). Clear oil, yield $80 \mathrm{mg}$ (0.29 mmol, 66\%). ${ }^{1} \mathrm{H}$ NMR (700 MHz, $\mathrm{D}_{2} \mathrm{O}$ ), $\delta: 5.03$ (br d, $J=7 \mathrm{~Hz}, 1 \mathrm{H}$ ), 4.43 (br t, $J=8 \mathrm{~Hz}, 1 \mathrm{H}$ ), 3.72 (br s, 3H), 3.69 (br s, 3H), 2.26 (br m, 3H), 1.77 (br m, 1H), 1.13 (s, 9H). ${ }^{13} \mathrm{C}\left\{{ }^{1} \mathrm{H}\right\}$ NMR (176 MHz, $\left.\mathrm{D}_{2} \mathrm{O}\right), \delta$ (all singlets): $180.7(\mathrm{C}=\mathrm{O}), 174.3(\mathrm{C}=\mathrm{O}), 174.0(\mathrm{C}=\mathrm{O}), 62.8(\mathrm{CH}), 60.8(\mathrm{CH})$, $53.0\left(\mathrm{CH}_{3} \mathrm{O}\right), 52.6\left(\mathrm{CH}_{3} \mathrm{O}\right), 39.2(\mathrm{C}), 31.1\left(\mathrm{CH}_{2}\right), 26.7\left(\mathrm{CH}_{3}\right), 25.4$ $\left(\mathrm{CH}_{2}\right)$. HMRS (ESI-orbitrap): calcd for $[\mathrm{M}+\mathrm{H}]^{+} \mathrm{C}_{13} \mathrm{H}_{22} \mathrm{NO}_{5}$ 272.1492 Da, found 272.1492 Th.

Dimethyl(r,r)-1-pivaloylpyrrolidine-2,5-dicarboxylate

(3b). White solid, yield $86 \mathrm{mg}(0.32 \mathrm{mmol}, 70 \%) .{ }^{1} \mathrm{H} \quad \mathrm{NMR}$ $\left(700 \mathrm{MHz}, \mathrm{D}_{2} \mathrm{O}\right), \delta: 5.14(\mathrm{~d}, J=8.5 \mathrm{~Hz}, 1 \mathrm{H}), 4.52(\mathrm{~d}, J=9.8 \mathrm{~Hz}$, $1 \mathrm{H}), 3.74(\mathrm{~s}, 3 \mathrm{H}), 3.67$ (s, 3H), $2.38(\mathrm{~m}, 1 \mathrm{H}), 2.19$ (dd, $J=13.2$, $6.6 \mathrm{~Hz}, 1 \mathrm{H}), 2.09$ (m, 1H), 1.92 (dd, $J=13.5,7.2 \mathrm{~Hz}, 1 \mathrm{H}), 1.12$ (s, 9H). ${ }^{13} \mathrm{C}\left\{{ }^{1} \mathrm{H}\right\}$ NMR (176 MHz, $\mathrm{D}_{2} \mathrm{O}$ ), $\delta$ (all singlets): 180.4 $(\mathrm{C}=\mathrm{O}), 175.1(\mathrm{C}=\mathrm{O}), 174.8(\mathrm{C}=\mathrm{O}), 61.9(\mathrm{CH}), 60.9(\mathrm{CH}), 53.4$ $\left(\mathrm{CH}_{3} \mathrm{O}\right), 52.8\left(\mathrm{CH}_{3} \mathrm{O}\right), 39.1(\mathrm{C}), 30.3\left(\mathrm{CH}_{2}\right), 26.5\left(\mathrm{CH}_{3}\right), 24.8$ $\left(\mathrm{CH}_{2}\right)$. HMRS (ESI-orbitrap): calcd for $[\mathrm{M}+\mathrm{H}]^{+} \mathrm{C}_{13} \mathrm{H}_{22} \mathrm{NO}_{5}$ 272.1492 Da, found 272.1494 Th. M.p. 80-85 ${ }^{\circ} \mathrm{C}$.

The synthesis of $\mathbf{5 b}$ was fully reproduced ${ }^{37}$ starting from $0.5 \mathrm{~g}$ of the racemic $\mathrm{HCl} \cdot \mathrm{H}-\mathrm{Pro}-\mathrm{OMe}(3.0 \mathrm{mmol}, 1 / 10$ scale of the reported synthesis). The product was a colorless oil. Yield $0.60 \mathrm{~g}$ (2.8 mmol, 92\%). ${ }^{1} \mathrm{H}$ NMR (700 MHz, $\mathrm{D}_{2} \mathrm{O}$ ), $\delta$ (s-trans rotamer only, $\mathrm{K}_{\text {trans/cis }}=46 \pm 2$ at $\left.298 \mathrm{~K}\right): 4.34(\mathrm{dd}, J=8.5,6.0$ $\mathrm{Hz}, 1 \mathrm{H}, \alpha-\mathrm{CH}), 3.79(\mathrm{dt}, J=10.6,6.5 \mathrm{~Hz}, 1 \mathrm{H}, \delta-\mathrm{CH}), 3.74(\mathrm{dt}, J=$ 10.6, $6.7 \mathrm{~Hz}, 1 \mathrm{H}, \delta-\mathrm{CH}), 3.67$ (s, 3H, $\left.\mathrm{CH}_{3} \mathrm{O}\right), 2.14(\mathrm{~m}, 1 \mathrm{H}$, $\beta-\mathrm{CH}), 1.98(\mathrm{~m}, 1 \mathrm{H}, \gamma-\mathrm{CH}), 1.92(\mathrm{~m}, 1 \mathrm{H}, \gamma-\mathrm{CH}), 1.79(\mathrm{~m}, 1 \mathrm{H}$, $\beta-\mathrm{CH}), 1.17$ (s, 9H, $\left.\left(\mathrm{CH}_{3}\right)_{3} \mathrm{C}\right)$.

Compound $\mathbf{4 b}$ was prepared as follows. Pyrrolidine $(1 \mathrm{ml}$, $12.2 \mathrm{mmol}$ ) was mixed with triethylamine $(3.4 \mathrm{ml}, 24.4 \mathrm{mmol}$, 2 equiv.) in dichloromethane $(20 \mathrm{ml})$. Pivaloyl chloride $(1.6 \mathrm{ml}$, 
$13.0 \mathrm{mmol}, 1.07$ equiv.) was added dropwise at room temperature (CAUTION: vigorous reaction!), and the mixture was stirred for an additional $30 \mathrm{~min}$. The solution was washed with water $(1 \times 5 \mathrm{ml}), 1: 2$ aqueous hydrochloric acid $(1 \times 5 \mathrm{ml})$ and $1 \mathrm{M}$ sodium hydrogen carbonate $(1 \times 5 \mathrm{ml})$; subsequently, it was dried over sodium sulphate, filtered and evaporated. Pure $4 \mathbf{b}$ was obtained as a colorless solid after crystallization from dichloromethane. Yield $1.80 \mathrm{~g}$ (11.6 mmol, 95\%). ${ }^{1} \mathrm{H}$ NMR $\left(700 \mathrm{MHz}, \mathrm{D}_{2} \mathrm{O}\right), \delta: 3.62(\mathrm{t}, J=6.1 \mathrm{~Hz}, 2 \mathrm{H}), 3.34(\mathrm{t}, J=6.7 \mathrm{~Hz}$, 2H), 1.86 (m, 2H), 1.73 (m, 2H), 1.16 (s, 9H). M.p. 57-63 ${ }^{\circ} \mathrm{C}$.

$N$-Acetylglycyl( $N$-aceturyl) compounds. $N$-Acetylglycyl( $N$-aceturyl) compounds were prepared under solution peptide coupling conditions. Aceturic acid (78 mg, $0.67 \mathrm{mmol}, 1.3$ equiv.) was mixed with benzotriazol-1-yl-oxytripyrrolidinophosphonium hexafluorophosphate (PyBOP, $346 \mathrm{mg}, 0.66 \mathrm{mmol}, 1.3$ equiv.) and diisopropylethylamine (120 $\mu \mathrm{l}, 0.69 \mathrm{mmol}, 1.35$ equiv.) in dichloromethane $(2 \mathrm{ml})$. After about $10 \mathrm{~min}$, the resulting solution was added to the mixture of $\mathrm{HCl} \cdot \mathrm{H}-(\mathrm{MeO})$ Pdc-OMe (Pdc = mPdc or $r$ Pdc, $113 \mathrm{mg}, 0.51 \mathrm{mmol})$ with diisopropylethylamine ( $220 \mu \mathrm{l}, 1.26 \mathrm{mmol}, 2.5$ equiv.) in dichloromethane $(4 \mathrm{ml})$. The mixture was stirred for about 10 hours. It was then washed with $1: 2$ aqueous hydrochloric acid $(1 \times$ $0.5 \mathrm{ml})$ and $1 \mathrm{M}$ sodium hydrogen carbonate $(1 \times 0.5 \mathrm{ml})$; subsequently, it was dried over sodium sulphate, filtered and evaporated. The resulting oil was extracted with water $(1.5 \mathrm{ml})$. The extract was filtered through a short cation-exchange column $(1.5 \mathrm{ml})$, and the elution was performed with water (about $5 \mathrm{ml}$ ). The aqueous fractions were collected and freeze-dried. Final purification was accomplished by silica gel chromatography (about $10 \mathrm{~g}$ ) using an ethyl acetate-methanol gradient elution (19:1-4:1-0:1). The resulting compounds were colorless glassy materials and were slightly acidic. Therefore, the NMR samples in deuterium oxide were buffered with potassium phosphate buffer (70 mM, pH 7) and contained $35 \mathrm{mM}$ of the analytes.

Dimethyl(r,s)-1-(acetylglycyl)pyrrolidine-2,5-dicarboxylate (2c). Yield $34 \mathrm{mg}$ (0.12 mmol, 24\%). ${ }^{1} \mathrm{H}$ NMR (700 MHz, $\left.\mathrm{D}_{2} \mathrm{O}\right)$, $\delta: 4.78(\mathrm{dd}, J=7.9,2.0 \mathrm{~Hz}, 1 \mathrm{H}), 4.47(\mathrm{t}, J=7.8 \mathrm{~Hz}, 1 \mathrm{H}), 4.08(\mathrm{~d}$, $J=17.3 \mathrm{~Hz}, 1 \mathrm{H}), 3.93(\mathrm{~d}, J=17.1 \mathrm{~Hz}, 1 \mathrm{H}), 3.75(\mathrm{~s}, 3 \mathrm{H}), 3.68(\mathrm{~s}$, $3 \mathrm{H}), 2.34-2.24(\mathrm{~m}, 3 \mathrm{H}), 1.98(\mathrm{~s}, 3 \mathrm{H}), 1.89(\mathrm{~m}, 1 \mathrm{H}) .{ }^{13} \mathrm{C}\left\{{ }^{1} \mathrm{H}\right\}$ NMR (176 MHz, $\left.\mathrm{D}_{2} \mathrm{O}\right), \delta$ (all singlets): $174.6(\mathrm{C}=\mathrm{O}), 173.8$ $(\mathrm{C}=\mathrm{O}), 172.8(\mathrm{C}=\mathrm{O}), 170.5(\mathrm{C}=\mathrm{O}), 60.6(\mathrm{CH}), 59.9(\mathrm{CH}), 53.2$ $\left(\mathrm{CH}_{3} \mathrm{O}\right), 52.9\left(\mathrm{CH}_{3} \mathrm{O}\right), 41.5\left(\mathrm{NH}-\mathrm{CH}_{2}\right), 29.4\left(\mathrm{CH}_{2}\right), 27.2\left(\mathrm{CH}_{2}\right)$, $21.6\left(\mathrm{CH}_{3}\right)$. HRMS (ESI-orbitrap): calcd for $[\mathrm{M}+\mathrm{H}]^{+}$ $\mathrm{C}_{12} \mathrm{H}_{19} \mathrm{~N}_{2} \mathrm{O}_{6} 287.1238 \mathrm{Da}$, found 230.1240 Th.

Dimethyl(r,r)-1-(acetylglycyl)pyrrolidine-2,5-dicarboxylate (3c). Yield $37 \mathrm{mg}$ (0.13 mmol, 26\%). ${ }^{1} \mathrm{H}$ NMR (700 MHz, $\mathrm{D}_{2} \mathrm{O}$ ), $\delta$ : $4.85(\mathrm{~d}, J=8.8 \mathrm{~Hz}, 1 \mathrm{H}), 4.56(\mathrm{~d}, J=9.4 \mathrm{~Hz}, 1 \mathrm{H}), 4.03(\mathrm{~d}, J=17.3$ $\mathrm{Hz}, 1 \mathrm{H}), 3.84$ (d, $J=17.3 \mathrm{~Hz}, 1 \mathrm{H}), 3.75(\mathrm{~s}, 3 \mathrm{H}), 3.69(\mathrm{~s}, 3 \mathrm{H})$, $2.36(\mathrm{~m}, 1 \mathrm{H}), 2.26(\mathrm{dd}, J=13.6,6.8 \mathrm{~Hz}, 1 \mathrm{H}), 2.17$ (m, 1H), 2.04 (dd, $J=13.5,7.0 \mathrm{~Hz}, 1 \mathrm{H}), 1.97$ (s, 3H). ${ }^{13} \mathrm{C}\left\{{ }^{1} \mathrm{H}\right\}$ NMR $(176 \mathrm{MHz}$, $\left.\mathrm{D}_{2} \mathrm{O}\right), \delta$ (all singlets): $174.5(\mathrm{C}=\mathrm{O}), 174.0(\mathrm{C}=\mathrm{O}), 173.5(\mathrm{C}=\mathrm{O})$, $170.4(\mathrm{C}=\mathrm{O}), 60.0(\mathrm{CH}), 59.7(\mathrm{CH}), 53.5\left(\mathrm{CH}_{3} \mathrm{O}\right), 53.0\left(\mathrm{CH}_{3} \mathrm{O}\right)$, $41.5\left(\mathrm{NH}-\mathrm{CH}_{2}\right), 29.3\left(\mathrm{CH}_{2}\right), 26.4\left(\mathrm{CH}_{2}\right), 21.5\left(\mathrm{CH}_{3}\right)$. HRMS (ESIorbitrap): calcd for $[\mathrm{M}+\mathrm{H}]^{+} \mathrm{C}_{12} \mathrm{H}_{19} \mathrm{~N}_{2} \mathrm{O}_{6} 287.1238 \mathrm{Da}$, found 230.1239 Th.
The other two peptides $\mathbf{4 c}$ and $5 \mathbf{c}$ were prepared under analogous conditions, by employing $N, N, N^{\prime}, N^{*}$-tetramethyl-O-( $N$ succinimidyl)uronium hexafluorophosphate (HSTU) as the coupling reagent. 4c, ${ }^{1} \mathrm{H}$ NMR (700 $\left.\mathrm{MHz}, \mathrm{D}_{2} \mathrm{O}\right), \delta: 3.93(\mathrm{~s}, 2 \mathrm{H})$, $3.40(\mathrm{t}, J=6.9 \mathrm{~Hz}, 2 \mathrm{H}), 3.33(\mathrm{t}, J=6.9 \mathrm{~Hz}, 2 \mathrm{H}), 1.98(\mathrm{~s}, 3 \mathrm{H})$, $1.90(\mathrm{~m}, 2 \mathrm{H}), 1.80$ (m, 2H). HRMS (ESI-orbitrap): calcd for [M + $\mathrm{H}]^{+} \mathrm{C}_{8} \mathrm{H}_{15} \mathrm{~N}_{2} \mathrm{O}_{2}$ 171.1128 Da, found 171.1129 Th. 5c, ${ }^{1} \mathrm{H}$ NMR $\left(700 \mathrm{MHz}, \mathrm{D}_{2} \mathrm{O}\right.$ ), $\delta$ (s-trans rotamer only, $K_{\text {trans } / \text { cis }}=6.15 \pm 0.27$ at $298 \mathrm{~K}): 4.41(\mathrm{dd}, J=9.0,4.4 \mathrm{~Hz}, 1 \mathrm{H}, \alpha-\mathrm{CH}), 4.03(\mathrm{~d}, J=17.3$ $\mathrm{Hz}, 1 \mathrm{H}), 3.98$ (d, $J=17.5 \mathrm{~Hz}, 1 \mathrm{H}), 3.68$ (s, 3H, $\left.\mathrm{CH}_{3} \mathrm{O}\right), 3.58$ (m, $1 \mathrm{H}, \delta-\mathrm{CH}), 3.54(\mathrm{~m}, 1 \mathrm{H}, \delta-\mathrm{CH}), 2.22(\mathrm{~m}, 1 \mathrm{H}, \beta-\mathrm{CH}), 1.98(\mathrm{~s}, 3 \mathrm{H})$, 1.97 (m, 2H, $\gamma-\mathrm{CH}_{2}$ ), 1.96 (m, 1H, $\beta-\mathrm{CH}$ ). HRMS (ESI-orbitrap): calcd for $[\mathrm{M}+\mathrm{H}]^{+} \mathrm{C}_{10} \mathrm{H}_{17} \mathrm{~N}_{2} \mathrm{O}_{4} 229.1183 \mathrm{Da}$, found 229.1182 Th.

\section{Physical chemistry}

The NMR measurements were performed by 700 and $500 \mathrm{MHz}$ ${ }^{1} \mathrm{H}$ NMR detection. The variable temperature unit was calibrated using acidified methanol sample measurements. ${ }^{38}$

The $\mathbf{p} K_{\mathrm{a}}$ measurements. The $\mathrm{p} K_{\mathrm{a}}$ measurements were performed at $298 \mathrm{~K}$ as described. ${ }^{16}$ Buffer samples were taken at different $\mathrm{pH}$ values. Deuterium oxide was added (1/10 to the buffer volume), and the analyte (methyl ester hydrochloride of an amino acid) solution in a little amount of deuterium oxide was added 1-2 min prior to the ${ }^{1} \mathrm{H}$ NMR measurement. The ${ }^{1} \mathrm{H}$ NMR spectra were recorded using W5 water suppression pulse tray. The final analyte concentration was $0.5-1 \mathrm{mM}$. The measurements were performed in $10 \mathrm{mM}$ phosphate buffer for pyrrolidine, $50 \mathrm{mM} / 60 \mathrm{mM}$ phosphate/glycine buffer for $\mathrm{HCl} \cdot \mathrm{H}-\mathrm{Pro}-\mathrm{OMe}$, and $20 \mathrm{mM} / 3 \mathrm{mM}$ phosphate/citric buffer for $\mathrm{HCl} \cdot \mathrm{H}-(\mathrm{MeO}) \mathrm{Pdc}-\mathrm{OMe}$ analytes. The standard error of the measured $\mathrm{p} K_{\mathrm{a}}$ values is \pm 0.10 . For pyrrolidine the obtained value 11.41 is consistent with the previously reported value of $11.35 .^{39}$

Partitioning. Partitioning was measured as follows. $5 \mathrm{mg}$ of a compound was shaken with octan-1-ol $(1.00 \mathrm{ml})$ and deionized water $(1.00 \mathrm{ml})$ at $298 \pm 2 \mathrm{~K}$ for 24 hours. Aliquots $(250 \mu \mathrm{l})$ were added to identical NMR tubes and diluted with methanol- $\mathrm{d}_{4}(200 \mu \mathrm{l})$ for locking and shimming. The concentration of the samples was measured in single scan 90-degree pulse ${ }^{1} \mathrm{H}$ NMR spectra recorded at $298 \mathrm{~K}$. Only the 90-degree pulses and zero-phase values were re-adjusted between the measurements. The method is similar to that recently reported by Linclau et al. based on ${ }^{19} \mathrm{~F}$ NMR detection. ${ }^{40}$ Found $\log P$ values: $2 \mathrm{a}-0.74 \pm 0.05,3 \mathrm{a}-0.43 \pm 0.03, \mathbf{4 a}-0.20 \pm 0.07,5 \mathrm{a}$ $-0.44 \pm 0.05$.

The amide rotation kinetics. The amide rotation kinetics were measured in ${ }^{1} \mathrm{H} z$-cross-relaxation experiments (NOESY/ EXSY with $z$-gradients) as described. ${ }^{16,19}$ The analyte concentration in the NMR samples was 30-80 mM. Different mixing times ( $15 \mathrm{~ms}-5 \mathrm{~s}$ ) between 2 and 5 were used for the exchange detection. The time domain in the direct dimension was 2048 points, whereas in the indirect dimension, this was set to yield sufficient resolution of the analysed resonances (160-512 points, resolution $5-30 \mathrm{~Hz}$ ). Recycling delay was $\geq 2 T_{1}$ of the analysed resonances. Note that the use of a high recycling 
delay is not necessary but improves the precision of the measurements. The exchange rate matrices were calculated using EXSYCalc (Mestrec), and the kinetic constants were converted to the activation energy values using the Eyring equation. The error of the activation energy values was calculated using the rate constant error and does not take into account the temperature calibration error. The results are summarized in the ESI in Table S1 $\left(E^{\neq}\right.$for $\mathbf{2 a - 4 a}$ at different temperatures), Table $\mathrm{S} 2$ ( $E^{\neq}$for $\mathbf{2 c - 4 c}$ at different temperatures), Table S3 (energetic terms for $\mathbf{2 a - 4 a}$ and $\mathbf{2 c - 4 c}$ ), Table S4 $\left(E^{\neq}\right.$in all compounds, $\mathrm{D}_{2} \mathrm{O}$ ), and Table $\mathrm{S} 5 \ddagger\left(E^{\neq}\right.$for $\mathbf{2 a - 4 a}$ in different solvents).

Molecular modelling. Molecular modelling was performed using Scigress Modelling 3.2 (Fujitsu, Poland). The PM6-water algorithm was used for semi-empirical calculations.

X-ray diffraction. X-ray diffraction measurements were performed at $150 \mathrm{~K}$. The $R$-factors for the calculated structures were 0.0257 (2a) and 0.0346 (3a).

\section{Conflicts of interest}

There is no conflict of interest to declare for this article.

\section{Acknowledgements}

VK acknowledges the DFG research group 1805 for a postdoctoral position and Synpeptide EU consortium for financial support. The authors are also grateful to Dr Marcie Jaffee (Atlanta, USA) for generous proof-reading of the manuscript.

\section{Notes and references}

1 The proline/sodium symport is utilized by some organisms for the uptake of proline as a nutrient: (a) C.-C. Chen, T. Tsuchiya, Y. Yamane, J. M. Wood and T. H. Wilson, J. Membr. Biol., 1985, 84, 157-164; (b) S. Moses, T. Sinner, A. Zaprasis, N. Stöveken, T. Hoffmann, B. R. Belitsky, A. L. Sonenshein and E. Bremen, J. Bacteriol., 2012, 194, 745-758; (c) H. Jung, D. Hilger and M. Raba, Front. Biosci., 2012, 1, 745-759.

2 (a) L. Szabados and A. Savouré, Trends Plant Sci., 2010, 15, 89-97; (b) I. Pérez-Arellano, F. Carmona-Álvarez, A. I. Martínez, J. Rodríguez-Díaz and J. Cervera, Protein Sci., 2010, 19, 372-382.

3 The ribosomal peptide bond formation for proline is slow compared to other amino acids: (a) M. Y. Pavlov, R. E. Watts, Z. Tan, V. W. Cornish, M. Ehrenberg and A. C. Forster, Proc. Natl. Acad. Sci. U. S. A., 2009, 106, 50-54; (b) L. K. Doerfel, I. Wohlgemuth, C. Kothe, F. Peske, H. Ulraub and M. V. Rodnina, Science, 2013, 339, 85-88; (c) L. K. Doerfel, I. Wohlgemuth, V. Kubyshkin, A. L. Starosta, D. N. Wilson, N. Budisa and M. V. Rodnina, J. Am. Chem. Soc., 2015, 137, 12997-13006.
4 (a) A. Farhat-Khemakhem, M. B. Ali, I. Boukhris, B. Khemachem, E. Maguin, S. Bejar and H. Chouayekh, Int. J. Biol. Macromol., 2013, 54, 9-15; (b) J. Huang, B. J. Jones and R. J. Kazlauskas, Biochemistry, 2015, 54, 4330-4341; (c) H. Yu, Y. Zhao, C. Guo, Y. Gan and H. Huang, Biochim. Biophys. Acta, Proteins Proteomics, 2015, 1854, 65-72.

5 Proline and its derivatives catalyse condensation reactions either as an organic additive: (a) S. Bertelsen and K. A. Jørgensen, Chem. Soc. Rev., 2009, 38, 2178-2189; (b) M. H. Haindl, J. Hioe and R. M. Gschwind, J. Am. Chem. Soc., 2015, 137, 12835-12842; or this could also be an $\mathrm{N}$-terminal proline residue in a short peptide: (c) J. Duschmalé, J. Wiest, M. Wiesner and H. Wennemers, Chem. Sci., 2013, 4, 1312-1318; (d) T. Schnitzer, M. Wiesner, P. Krattiger, J. D. Revell and H. Wennemers, Org. Biomol. Chem., 2017, 15, 5877-5881; or a protein: (e) M. Rahimi, E. M. Geertsema, Y. Miao, J.-Y. van der Meer, T. van den Bosch, P. de Haan, E. Zandvoort and G. J. Poelarends, Org. Biomol. Chem., 2017, 15, 2809-2816.

6 Studies suggest a role of proline in the homochirality transfer from amino acids to sugars: J. E. Hein and D. G. Blackmond, Acc. Chem. Res., 2012, 45, 2045-2054.

7 (a) S. Kheria, R. V. Nair, A. S. Kotmale, P. R. Rajamohanan and G. J. Sanjayan, New J. Chem., 2015, 39, 3327-3332; (b) N. D. Bansode, M. V. Sonar and K. N. Ganesh, Chem. Commun., 2016, 52, 4884-4887.

8 I. E. Sampaio-Dias, C. A. D. Sousa, X. García-Mera, J. F. da Costa, O. Caamaño and J. E. Rodríguez-Borges, Org. Biomol. Chem., 2016, 14, 11065-11069.

9 cis-trans-Isomerization in Biochemistry, ed. C. Dugave, Wiley, Weinheim, 2006.

10 (a) S. Fischer, S. Michnick and M. Karplus, Biochemistry, 1993, 32, 13830-13837; (b) C. Cox and T. Lectka, Acc. Chem. Res., 2000, 33, 849-858; (c) K. P. Lu, G. Finn, T. H. Lee and L. K. Nicholson, Nat. Chem. Biol., 2007, 3, 619-629.

11 G. Fischer, Chem. Soc. Rev., 2000, 29, 119-127.

12 (a) G. Fischer, Angew. Chem., Int. Ed. Engl., 1994, 33, 14151436; (b) S. F. Göthel and M. A. Marahiel, Cell. Mol. Life Sci., 1999, 55, 423-436.

13 Examples of folding kinetics affected by the incorporation of fluoroprolines: in $\beta 2$-microglobulin; (a) V. Yu. Torbeev and D. Hilvert, Proc. Natl. Acad. Sci. U. S. A., 2013, 110, 2005120056 in thioredoxin; (b) D. Roderer, R. Glockshuber and M. Rubini, ChemBioChem, 2015, 16, 2162-2166.

14 (a) V. Kubyshkin and N. Budisa, submitted; (b) D. Kern, M. Schutkowski and T. Drakenberg, J. Am. Chem. Soc., 1997, 119, 8403-8408; (c) G. Scherer, M. L. Kramer, M. Schutkowski, U. Reimer and G. Fischer, J. Am. Chem. Soc., 1998, 120, 5568-5574; (d) J. Zhang and M. W. German, Biopolymers, 2011, 95, 755-762.

15 N. W. Owens, C. Braun, J. D. O'Neil, K. Marat and F. Schweizer, J. Am. Chem. Soc., 2007, 129, 11670-11671.

16 V. Kubyshkin, P. Durkin and N. Budisa, New J. Chem., 2016, 40, 5209-5220.

17 M. D. Shoulders and R. T. Raines, Annu. Rev. Biochem., 2009, 78, 929-958. 
18 S. Busch, C. D. Bruce, C. Redfield, C. D. Lorenz and S. E. McLain, Angew. Chem., Int. Ed., 2013, 52, 13091-13095.

19 V. Kubyshkin and N. Budisa, Org. Biomol. Chem., 2017, 15, 619-627.

20 (a) V. Somayaji and R. S. Brown, J. Org. Chem., 1986, 51, 2676-2686; (b) A. J. Kirby, I. V. Komarov, P. D. Wothers and N. Feeder, Angew. Chem., Int. Ed., 1998, 37, 785-786; (c) A. J. Kirby, I. V. Komarov and N. Feeder, J. Am. Chem. Soc., 1998, 120, 7101-7102; (d) J. Clayden and W. J. Moran, Angew. Chem., Int. Ed., 2006, 45, 7118-7120; (e) I. V. Komarov, S. Yanik, A. Yu. Ishchenko, J. E. Davies, J. M. Goodman and A. J. Kirby, J. Am. Chem. Soc., 2015, 137, 926-930; (f) R. Szostak, J. Aubé and M. Szostak, J. Org. Chem., 2015, 80, 7905-7927; $(g)$ M. Liniger, D. G. VanderVelde, M. K. Takase, M. Shahgholi and B. M. Stolz, J. Am. Chem. Soc., 2016, 138, 969-974.

21 The early computational analysis of AcProNHMe suggested that the syn/exo and anti/endo transition states are most favoured, with the energy difference of about $6 \mathrm{~kJ} \mathrm{~mol}^{-1}$, whereas no saddle point was found for the syn/endo state, due to the steric repulsion between the $\mathrm{N}$ - and C-terminal groups in this transition state: S. Fischer, R. L. Dunbrack Jr. and M. Karplus, J. Am. Chem. Soc., 1994, 116, 11931-11937.

22 S. Adachi, N. Kumagai and M. Shibasaki, Chem. Sci., 2017, 8, 85-90.

23 See, for example: (a) Y. K. Kang and H. Y. Choi, Biophys. Chem., 2004, 111, 135-142; (b) A. E. Aliev, S. Bhandal and D. Courtier-Murias, J. Phys. Chem. A, 2009, 113, 1085810865; (c) J. Chen, S. A. Edwards, F. Gräter and C. Baldauf, J. Phys. Chem. B, 2012, 116, 9346-9351.

24 E. Vöhringer-Martinez, F. Duarte and A. Toro-Labbé, J. Phys. Chem. B, 2012, 116, 12972-12979.

25 A. Y. Mercedez-Camacho, A. B. Mullins, M. D. Mason, G. G. Xu, B. J. Mahoney, X. Wang, J. W. Peng and F. A. Etzkorn, Biochemistry, 2013, 52, 7707-7713.

26 C. Cox and T. Lectka, J. Am. Chem. Soc., 1998, 120, 1066010668.
27 The structures have been deposited in Cambridge Crystallographic Data Centre under the deposition numbers: 2a - CCDC 1554475, 3a - CCDC 1554476.

28 M. Cai, Y. Huang, J. Liu and R. Krishnamoorthi, J. Biomol. NMR, 1995, 6, 123-128.

29 R. W. Newberry and R. T. Raines, Acc. Chem. Res., 2017, DOI: 10.1021/acs.accounts.7b00121.

30 C. Siebler, B. Maryasin, M. Kuemin, R. S. Erdmann, C. Rigling, C. Grünenfelder, C. Ochsenfeld and H. Wennemers, Chem. Sci., 2015, 6, 6725-6730.

31 C. Renner, S. Alefelder, J. H. Bae, N. Budisa, R. Huber and L. Moroder, Angew. Chem., Int. Ed., 2001, 40, 923-925.

32 Somehow higher activation entropy values have been reported for 5a in E. S. Eberhardt, N. Panasik Jr. and R. T. Raines, J. Am. Chem. Soc., 1996, 118, 12261-12266.

33 3-Fluoroprolines; (a) C. A. Thomas, E. R. Talaty and J. G. Bann, Chem. Commun., 2009, 3366-3368; and 4-trifluoromethylproline; (b) V. Kubyshkin, S. Afonin, S. Kara, N. Budisa, P. K. Mykhailiuk and A. S. Ulrich, Org. Biomol. Chem., 2015, 13, 3171-3181.

34 4-Fluoroproline, see ref. 31; 4-hydroxyproline and its $O$-glycosylated derivatives, see ref. 15, 4-azidoproline see L.-S. Sonntag, PhD Thesis, Basel University, 2005.

35 (a) E. S. Eberhardt, S. N. Loh, A. P. Hinck and R. T. Raines, J. Am. Chem. Soc., 1992, 114, 5437-5439; (b) C. Cox and T. Lectka, J. Org. Chem., 1998, 63, 2426-2427.

36 V. S. Kubyshkin, P. K. Mykhailiuk and I. V. Komarov, Tetrahedron Lett., 2007, 48, 4061-4063.

37 D. N. Reddy, R. Thirupathi, S. Tumminakatti and E. N. Prabhakaran, Tetrahedron Lett., 2012, 53, 44134417.

38 A. L. Van Geet, Anal. Chem., 1970, 42, 679-680.

39 V. Frenna, N. Vivona, G. Consiglio and D. Spinelli, J. Chem. Soc., Perkin Trans. 2, 1985, 1865-1868.

40 B. Linclau, Z. Wang, G. Compain, V. Paumelle, C. Q. Fontenelle, N. Wells and A. Weymouth-Wilson, Angew. Chem., Int. Ed., 2016, 55, 674-678. 